\title{
Elderly victims of abuse: a five year document analysis
}

\section{Abstract}

Objective: To verify the occurrence of maltreatment of the elderly and its characteristics (location, type, reason, involvement of alcohol/drugs, profile and family relationship of victims and perpetrators) from the police records of a specialized police station over a five year period. Method: A cross-sectional, descriptive and documentary analytical study was performed. The police reports of a medium-sized municipality in the northwest of São Paulo were analyzed from 2008 to 2012. The sociodemographic characteristics of the perpetrators and victims and the data relating to the aggression investigated were: violence; location; reason; the presence of alcohol and drugs during the assault and victim-offender relationship. Data was tabulated using descriptive statistical analysis. Results: Of a total of 572 cases, most of the perpetrators were men (69.2\%), Caucasian (56.5\%), aged $31-40$ years $(14.20 \%)$ with no information regarding occupation provided $(50.70 \%)$; most of the victims were women (93.0\%), Caucasian $(71.5 \%)$, aged $60-65$ years $(46.30 \%)$, married (34.10\%) and unemployed/retired (59.98\%). Emotional abuse was prevalent $(57.0 \%)$, occurred in the home of the elderly person $(81.3 \%)$ and the children of the elderly were the main perpetrators $(25.3 \%)$. The motives were related to arguments in most cases (53.1\%). Conclusion: Women who were Caucasian, married, aged 60-65, unemployed/retired were the main victims, with the perpetrators most frequently their own children, also Caucasian, single and aged 31-40 years. Psychological violence was the most prevalent, primarily triggered by disagreements among those involved, and it occurred most frequently in the residence of the victim. Most of the attackers were not under the influence of alcohol/drugs.
Cléa Adas Saliba Garbin' Renata Colturato Joaquim? Tânia Adas Saliba Rovida' Artênio José Isper Garbin?
Key words: Violence; Domestic Violence; Elderly; Elder Abuse. 


\section{INTRODUCTION}

The elderly population has increased rapidly in almost every country in the world. Alongside this growth have come hidden problems, such as abuse, exploitation and neglect of these individuals. ${ }^{1}$

For Action on Elder Abuse, a specialist institution in the UK, violence is defined as: "a single or repeated act or lack of appropriate action, occurring within any relationship where there is an expectation of trust, which causes harm or distress to an older person". ${ }^{2}$ In general, forms of violence are classified in accordance with the following categories: Pbysical abuse - cause pain or injury, exercise physical coercion or restrict freedom of movement by force or drug use; emotional abuse - inflict mental suffering; economic or material abuse - exploit the elderly person or make use of his or her income or material resources unlaw fully or improperly; sexual abuse - carry out non-consensual sexual contact of any kind with an elderly person; negligence - fail to comply with the obligation to provide the elderly person with his or her basic needs such as hygiene, food, affection or health care. ${ }^{3}$

While the phenomenon of violence against the elderly has been widely discussed among the international scientific community, and is recognized as a serious public health problem, the actions used to deal with the problem have taken the form of sporadic initiatives, followed by periods of apathy among researchers, national governments, international organizations and the general public. ${ }^{4}$

Thus, violence against the elderly has been one of the last forms of family related violence to attract the attention of society. ${ }^{5}$ Yet this is a population group that is highly vulnerable to abuse, requiring greater health care and which may be physically or mentally dependent. ${ }^{6}$

One of the great difficulties in relation to the diagnosis of family violence concerns secrecy or family collusion, which results in abused elderly persons failing to accuse their abusers. This phenomenon is linked to honor, complicity, the trust established within the family environment, the victim's fear of breaking these ties, as well as the authoritarianism and psychological pressure exercised by the aggressor.?

Elderly victims of abuse often experience feelings of powerlessness, alienation, guilt, shame, fear, anxiety, denial, post-traumatic disorder and experiences of depression, and a greater risk of death. ${ }^{8,9}$

Some factors may increase the risk of aggression, such as a lack of financial resources, previous experience of violent events among family members, drug abuse, mental health problems and high levels of stress. ${ }^{10}$

The scarcity of information regarding these cases should be noted. This is primarily as a result of the reluctance of elderly individuals to report abuse and aggression, because of embarrassment and fear of repression from caregivers, who are commonly themselves the aggressors. ${ }^{11}$

The present study aimed to verify the occurrence of maltreatment of the elderly and its characteristics (location, type, reason, involvement of alcohol/drugs, profile and family relationship of victims and aggressors), based on the records of a specialized police station during the period 2008-2012.

\section{METHOD}

A cross-sectional, descriptive and retrospective study, based on document analysis, was conducted at the Delegacia de Defesa da Mulher (Women's Police Station) (DDM) of a medium-sized municipality, located in the north-west of the state of São Paulo. This is the only police station to register occurrences involving the elderly, women and children. The collection was based on police records: police reports and misdemeanor reports. The police report is the initial registration of the offense, with the basic data of the facts and the parties involved. In some cases, however, misdemeanor reports are used for crimes considered to be less serious. 
All police reports and misdemeanor reports for the years 2008-2012 were analyzed, and all crimes committed against elderly persons of both genders were included in the study. These police records were classified according to the criteria used by the World Health Organization: physical abuse, emotional abuse, financial or material abuse, sexual abuse and neglect, to facilitate analysis of the data. ${ }^{3}$ Selfinflicted crimes, or in other words those committed by the victims themselves, were excluded from the study. The following variables were analyzed in the documents:

- Aggression: type of violence, location it occurred, motive, victim-aggressor relationship. The presence of alcohol and drugs during the aggression, according to the victim's account, was also considered.

- The sociodemographic characteristics of the aggressors and the victims: gender, age, race/ethnicity, marital status and occupation.

The collected data was entered into a spreadsheet created using Epi Info. After data processing, descriptive statistical analysis was carried out.

The study was approved by the Comitê de Ética em Pesquisa da Faculdade de Odontologia de Araçatuba da Universidade Estadual Paulista
(Ethics Research Committee of the Araçatuba Dental School of Paulista State University), under registration $\mathrm{n}^{\circ} 0829 / 10$, in accordance with the precepts of the Declaration of Helsinki and the Nuremberg Code, respecting the guidelines for human research (Resolution no. 196/96) of the National Health Council. ${ }^{12}$ The identity of the victims and perpetrators were kept secret by concealing their names or any other information that could identify them in the documents analyzed. The study was carried out following approval from the responsible individual at the Women's Police Station.

\section{RESULTS}

In the period 2008-2012, 10,884 police reports and 1,644 misdemeanor reports were registered at the Women's Police Station, of which 579 corresponded to crimes against the elderly. Seven cases of attempted suicide were excluded. Therefore, the study universe was composed of 572 police records.

Table 1 shows the socio-demographic characteristics of the victims and aggressors with regard to gender, race/ethnicity, age, marital status and occupation.

Table 1. Absolute and percentage distribution of sociodemographic characteristics of victims and aggressors of abuse of elderly individuals registered at the police station between 2008 and 2012. Araçatuba, SP, 2014.

\begin{tabular}{l|cc|cc}
\multicolumn{1}{c|}{ Variables } & \multicolumn{2}{c|}{ Victims } & \multicolumn{2}{c}{ Aggressors } \\
& $\mathrm{n}$ & $\%$ & $\mathrm{n}$ & $\%$ \\
\hline Gender & & & & \\
$\quad$ Male & 40 & 7.00 & 396 & 69.20 \\
$\quad$ Female & 532 & 93.00 & 142 & 24.80 \\
$\quad$ Information not given & - & - & 34 & 6.00 \\
\hline Ethnicity & & & & \\
Caucasian & 409 & 71.50 & 323 & 56.50 \\
Afro-Brazilian & 27 & 4.70 & 26 & 4.50 \\
Mixed Race & 89 & 15.60 & 129 & 22.50 \\
Information not given & 47 & 8.20 & 94 & 16.50 \\
\hline
\end{tabular}




\begin{tabular}{|c|c|c|c|c|}
\hline \multirow[t]{2}{*}{ Variables } & \multicolumn{2}{|c|}{ Victims } & \multicolumn{2}{|c|}{ Aggressors } \\
\hline & $\mathrm{n}$ & $\%$ & $\mathrm{n}$ & $\%$ \\
\hline \multicolumn{5}{|l|}{ Age group } \\
\hline $10 \mid--20$ & - & - & 23 & 4.00 \\
\hline $21 \mid--30$ & - & - & 49 & 8.60 \\
\hline $31 \mid--40$ & - & - & 81 & 14.20 \\
\hline $41 \mid--50$ & - & - & 78 & 13.70 \\
\hline $51 \mid--60$ & - & - & 39 & 6.80 \\
\hline $60 \mid--65$ & 265 & 46.30 & 54 & 9.40 \\
\hline $66 \mid--70$ & 136 & 23.80 & - & - \\
\hline $71 \mid--75$ & 75 & 13.15 & - & - \\
\hline $76 \mid--80$ & 59 & 10.30 & - & - \\
\hline$>80$ & 35 & 6.10 & - & - \\
\hline Information not given & 2 & 0.35 & 248 & 43.30 \\
\hline \multicolumn{5}{|l|}{ Marital status } \\
\hline Married/stable union & 195 & 34.10 & 125 & 21.80 \\
\hline Separated/divorced & 101 & 17.66 & 49 & 8.60 \\
\hline Single & 59 & 10.30 & 152 & 26.60 \\
\hline Widowed & 166 & 29.02 & 1 & 0.20 \\
\hline Information not given & 51 & 8.92 & 245 & 42.80 \\
\hline \multicolumn{5}{|l|}{ Occupation } \\
\hline Domestic & 11 & 1.93 & 2 & 0.36 \\
\hline Self-employed & 49 & 8.58 & 34 & 5.95 \\
\hline Retired/unemployed & 343 & 59.98 & 94 & 16.42 \\
\hline Others & 67 & 11.71 & 152 & 26.57 \\
\hline Information not given & 102 & 17.80 & 290 & 50.70 \\
\hline
\end{tabular}

Table 2 shows data related to the police records, such as the type of violence, the place where the aggression occurred, the reason for the abuse and whether alcohol or drugs were used at the time of aggression.
Table 3 shows the family relationship among the aggressors and victims divided into three groups: group A - marital relationship, group B family relationship and group $\mathrm{C}$ - other attackers with no close relationship with the victim. 
Table 2. Absolute and percentage distribution of police reports of cases of abuse against elderly individuals registered at the police station between 2008 and 2012. Araçatuba, SP, 2014.

\begin{tabular}{|c|c|c|}
\hline Variables & $\mathrm{N}$ & $\%$ \\
\hline \multicolumn{3}{|l|}{ Type of violence } \\
\hline Fatal & 1 & 0.17 \\
\hline Negligence & 12 & 2.10 \\
\hline Physical violence & 160 & 28.00 \\
\hline Psychological violence & 326 & 57.00 \\
\hline Sexual violence & 7 & 1.20 \\
\hline Others & 66 & 11.53 \\
\hline \multicolumn{3}{|l|}{ Location of occurrence } \\
\hline Care facility & 1 & 0.20 \\
\hline Own home & 465 & 81.30 \\
\hline Public space & 62 & 10.90 \\
\hline Other & 42 & 7.30 \\
\hline Information not given & 2 & 0.30 \\
\hline \multicolumn{3}{|l|}{ Reason for aggression } \\
\hline Jealousy & 6 & 1.05 \\
\hline Money/material goods & 90 & 15.80 \\
\hline Argument/misunderstanding & 304 & 53.10 \\
\hline Offspring & 6 & 1.05 \\
\hline Motive not described & 162 & 28.30 \\
\hline Other & 4 & 0.70 \\
\hline \multicolumn{3}{|l|}{ Alcohol } \\
\hline Yes & 80 & 14.00 \\
\hline No & 492 & 86.00 \\
\hline \multicolumn{3}{|l|}{ Drugs } \\
\hline Yes & 64 & 11.20 \\
\hline No & 508 & 88.80 \\
\hline
\end{tabular}


Table 3. Absolute and percentage distribution of relationship between aggressors and victims of abuse against elderly individuals registered at the police station between 2008 and 2012. Araçatuba, SP, 2014.

\begin{tabular}{lcc}
\hline \multicolumn{1}{c}{ Victim-aggressor relationship } & $\mathrm{n}$ & $\%$ \\
\hline Group A & 72 & 12.60 \\
Spouse & 19 & 3.30 \\
Ex-spouse & & \\
\hline Group B & 145 & 25.30 \\
Son & 22 & 3.90 \\
Brother or sister & 28 & 4.90 \\
Grandchild & & \\
\hline Group C & 125 & 21.80 \\
Others & 9 & 1.60 \\
Unknown & 71 & 12.40 \\
Neighbor & 81 & 14.20 \\
Information not given & 572 & 100.00 \\
\hline Total & & \\
\hline
\end{tabular}

\section{DISCUSSION}

In this study, the rate of cases of ill-treatment of elderly individuals registered in the police station studied was $4.62 \%$, which can be considered low when compared to all the incidents recorded in this police station. This fact can be explained by the unusual nature of the police station in question. Often elderly men may feel embarrassed to file complaints at a station run by female police officers. This may also explain the high incidence of female victims in this and other studies. ${ }^{13-15}$ Historically women fulfill a role of dependency to men, meaning that despite recently gaining their independence, they still suffer the consequences of a sexist and violent society. ${ }^{16}$ The importance of gender violence should therefore be noted, as women continue to be the main victims of domestic violence. ${ }^{6}$

The most prevalent age range among the victims was from 60 to 65 , suggesting that the degree of independence of the elderly persons is directly related to age, as more independent individuals can seek help more easily.
Most of the victims were married and lived at home, findings that agree with other studies in literature ${ }^{17-19}$ and suggest a certain dependency, which can increase the risk of becoming a victim.

Regarding the race of aggressors and victims, both revealed a higher proportion of Caucasian elderly persons, the predominant population of the municipal district. ${ }^{20}$ However, the identification of skin color is still a complex and controversial issue, and there is no consensus on this classification. ${ }^{21}$

In terms of the profile of the aggressor, it was noted that the majority were male and had a close relationship with the victim. This situation can be explained by the fragility of family relations, where individuals are put under strain by their daily problems, as the main motive for aggression were arguments and misunderstanding. The condition of living in the same home, often imposed by the economic and structural situation of the family, becomes one of the major risk factors for the occurrence of violence. ${ }^{13-15}$ Sometimes abuse is a continuation of longstanding patterns of physical or emotional abuse within the family. ${ }^{1,10,22}$ In this 
context, it can be seen why most of the events occurred within households.

The use of alcohol and drugs by family members can also increase the risk of agression. ${ }^{1,14}$ However, the findings of the present study revealed a low rate of consumption at the time of the events, suggesting a possible lack of information in the reports of the victims, as the data recorded is dependent on the veracity of the testimony.

One of the most important factors related to violence against the elderly is underreporting. The elderly person may not report the abuse due to factors such as fear of suffering retaliation, fear of being institutionalized in a nursing home or that his or her caregiver will be legally prejudiced, guilt, embarrassment, low self-esteem and the feeling that the abuse was deserved., ${ }^{1,23}$

Regarding the type of events, the most prevalent was psychological violence. Such abuse includes verbal abuse, threats, social isolation, among other acts capable of inflicting mental suffering upon the elderly. The issue of the dependency of the elderly in seeking help and assistance for the performance of daily activities can provoke this type of abuse, when associated with the stress undergone by the caregiver and his or her lack of preparation. ${ }^{18,24}$

Another notable finding of this study relates to the lack of information regarding the characteristics of the aggressor (Table 1). This information is very important for identifying the context in which this kind of violence occurs. It is therefore proposed, as a recommendation for future studies, that a procedure that incorporates data that supports adequate documentation of the occurrence of abuse against the elderly individual is created in order to help professionals record such events, as well as assist other researchers in the areas of Geriatrics and Gerontology.

While Brazil possesses a solid legal framework with regard to the defense of the rights of the elderly, much remains to be done. Further studies should therefore be encouraged so that the real needs of this community are met, thus creating preventive actions to combat this major public health problem.

Some limiting factors of this study should be considered, such as the lack of common definitions and concepts that allow the collection of standardized data and address the lack of information in current records, which make it difficult to visualize the social problem of the illtreatment for the elderly. The social and cultural diversity found in different regions of the country, making a definition of the scale and characterization of this kind of violence a challenge, should be considered. Although the present study was conducted in only one municipality, the relevance and justification of the work contributes to the knowledge of the problem and should therefore be expanded to other municipalities.

\section{CONCLUSION}

In conclusion, in the municipality studied, Caucasian married women aged 60 to 65 who are unemployed and/or retired are the main victims, and the aggressors are their own children, who are also Caucasians, single and aged between 31 and 40 years. Psychological violence was the most prevalent type, primarily triggered by disagreements among those involved, and taking place in the home of the victim. Most of the attackers were not under the influence of alcohol and/or drugs.

\section{REFERENCES}

1. Bond MC, Butler KH. Elder abuse and neglect definitions, epidemiology, and approaches to emergency department screening. Clin Geriatr Med 2013;29:257-73.
2. Action on Elder Abuse? [Internet]. Streatham: Action on Elder Abuse; 1995- . What is elder abuse?; 2015 [acesso em 15 set. 2015]; [aproximadamente 2 telas]. Disponível em: http://www.elderabuse.org.uk/ 
3. World Health Organization [Internet]. Geneve: WHO; 1995- . Action on Elder Abuse. What is elder abuse? 1995 [acesso em 5 set. 2015]; [aproximadamente 2 telas]. Disponível em: http:// www.who.in/ violence_injury_prevention

4. Podnieks E, Penhale B, Goergen T, Biggs S, Dongnee H. Elder mistreatment: an international narrative. J Elder Abuse Negl 2010;22(1-2):131-63.

5. Mahoney J. Types of abuse. Nurs Clin North América 2011;46(4):385-90.

6. Brasil. Ministério da Saúde, Secretaria de Políticas de Saúde.Violência intrafamiliar: orientações para prática em serviço. Brasília, DF: Ministério da Saúde; 2002

7. Faleiros VP. Violência contra a pessoa idosa: ocorrências, vítimas e agressores. Brasília, DF: Universa; 2007.

8. Minayo MCS, Coimbra CE Junior, organizadores. Antropologia, envelhecimento e saúde. Rio de Janeiro: Fiocruz; 2002. Entre a liberdade e a dependência: reflexões sobre o fenômeno social do envelhecimento. p. 11-24.

9. Minayo MCS, Souza ER, organizadores. As múltiplas mensagens da violência contra idosos. Rio de Janeiro: Fiocruz; 2003. Violência sobre o olhar da saúde: a infra-política da contemporaneidade brasileira. p. 223-42.

10. Acierno R, Hernandez MA, Amstadter AB, Resnick HS, Steve K, Muzzy W, et al. Prevalence and correlates of emotional, physical, sexual, and financial abuse and potential neglect in the United States: the National Elder Mistreatment Study. Am J Public Health 2010;100(2):292-7.

11. Minayo MCS. Violência contra idosos: relevância para um velho problema. Cad Saúde Pública 2003;19(3):783-91.

12. World Medical Association [Internet]. FerneyVoltaire: WMA; 1964- . Declaration of Helsinki; 1964 [acesso em 18 dez. 2014]; [aproximadamente 2 telas]. Disponível em: http:// www.wma.net

13. Clancy M, Mcdaid B, O’Neill D, O’Brien JG. National profiling of elder abuse referrals. Age Ageing 2011;40(3):346-52.

14. Abath MB, Leal MCC, Melo DA Filho. Fatores associados à violência doméstica contra a pessoa idosa. Rev Bras Geriatr Gerontol 2012;15(2):305-14.
15. Oliveira AAV, Trigueiro DRSG, Fernandes MGM, Silva, AO. Maus-tratos a idosos: revisão integrativa da literatura. Rev Bras Enferm 2013;66(1):128-33.

16. Salivkar S. Domestic violence: a problem. Indian J Appl Res [Internet] 2013 [acesso em 18 dez 2014];3(5):596-97. Disponível em: http://www. theglobaljournals.com/ijar/articles.php?val=MTU3M $\mathrm{A}==\#$ sthash.38FCFu1d.dpuf

17. MoraesCL, Apratto PC Junior, Reichenheim ME. Rompendo o silêncio e suas barreiras: um inquérito domiciliar sobre a violência doméstica contra idosos em área de abrangência do Programa Médico de Família de Niterói, Rio de Janeiro, Brasil. Cad Saúde Pública 2008;24(10):2289-300.

18. Nogueira CF, Freitas MC, Almeida PC. Violência contra idosos no município de Fortaleza, CE: uma análise documental. Rev Bras Geriatr Gerontol 2011;14(3):543-54.

19. Dossi AP, Garbin CAS, Garbin AJI, Saliba O. Perfil epidemiológico da violência física intrafamiliar: agressões denunciadas em um município do Estado de São Paulo, Brasil, entre 2001 e 2005. Cad Saúde Pública 2008;24(8):1939-52.

20. Instituto Brasileiro de Geografia e Estatística [Internet]. Rio de Janeiro: IBGE; 1995 - . Censo Demográfico de 2000; 2000 [acesso em 25 out. 2014]; [aproximadamente 2 telas]. Disponível em: https://www.seade.gov.br/produtos/idr/download/ populacao.pdf.

21. Cecilio LPP, Garbin CAS, Rovida TAS, Queiróz APDG, Garbin AJI. Interpersonal violence: descriptive study of not fatal cases assisted in an emergency reference unity to seven municipalities of the state of São Paulo,Brazil, from 2008 to 2010. Epidemiol Serv Saúde 2012;21(2):293-304.

22. Yaffe M, Tazkarji B. Understanding elder abuse in family practice. Can Fam Physician 2012;58(12):133640.

23. Hernandez-Tejada MA, Amstadter A, Muzzy W, Acierno R. The national elder mistreatment study: race and ethnicity findings. J Elder Abuse Negl 2013;25(4):281-93

24. Melo VL, Cunha JOC, Falbo Neto GH. Maustratos contra idosos no município de Camaragibe, Pernambuco. Rev Bras Saúde Mater Infant 2006;6(1):43-8. 